\title{
PENERAPAN METODE PERMAINAN KARTU KWARTET UNTUK MENINGKATKAN PRESTASI BELAJAR DAN KEAKTIFAN BELAJAR PADA MATERI KLASIFIKASI MAKHLUK HIDUP KELAS VII SMP N 1 SEMIN
}

\author{
Susi Prasetyaningtyas \\ SMP N 1 Semin \\ susiprasetya@rocketmail.com
}

\begin{abstract}
Abstrak: Penelitian ini bertujuan untuk meningkatkan prestasi belajar dan keaktifan belajar siswa kelas VII pada materi Klasifikasi Makhluk Hidup melalui penerapan metode permainan kartu kwartet dan mengetahui respon siswa terhadap penerapan metode permainan kartu kwartet. Penelitian yang dilaksanakan adalah Penelitian Tindakan Kelas (PTK). Penelitian ini dilaksanakan 2 siklus dan masing-masing siklus 2 kali pertemuan. Subyek penelitian adalah siswa kelas 7C SMP N 1 Semin Gunungkidul. Hasil penelitian ini menunjukkan bahwa penerapan metode permainan kartu kwartet pada materi Klasifikasi Makhluk Hidup dapat meningkatkan prestasi belajar dan keaktifan belajar siswa. Prestasi belajar ditunjukkan dengan naiknya presentase ketuntasan belajar. Pada prasiklus adalah 6,25\% dengan kategori sangat rendah, siklus I adalah 68,75\% dengan kategori sedang dan siklus II adalah 84,375\% dengan kategori tinggi. Keaktifan belajar menunjukkan kenaikan skor ratarata, yaitu siklus I adalah 64\% dengan kategori sedang dan siklus II menjadi 87,5\% dengan kategori tinggi. Respon siswa menunjukkan $100 \%$ siswa senang terhadap penerapan metode permainan kartu kwartet.
\end{abstract}

Kata kunci: metode permainan, kartu kwartet, keaktifan, prestasi belajar, klasifikasi makhluk hidup.

\section{APPLICATION QUARTER-CARDS GAME OF METHODS TO IMPROVE LEARNING ACHIEVEMENT AND LEARNING ACTIVITIES IN CLASSIFICATION OF LIVING THINGS AT CLASS VII C SMP N 1 SEMIN}

\begin{abstract}
This research was aimed to improve learning achievement and learning activeness of class VII on the Classification of Living Things by apllying of the quartet-card game method and knowing the students' responses to the application of the quartet-card game method. The research was Classroom Action Research (CAR). This research was conducted in 2 cycles and each cycle had 2 meetings. The research subjects were $7 C$ class students of SMP N 1 Semin Gunungkidul. The results of this research indicates that learning by applying the quartet-card game method of the Classification of Living Things can improve learning achievement and student learning activeness. Learning achievement is shown by increasing the percentage of mastery learning. In the pre-cycle is $6.25 \%$ with a very low category, the first cycle is $68.75 \%$ with a moderate category and the second cycle is $84.375 \%$ with a high category. Learning activeness showed an increase in average score, i.e. the first cycle was $64 \%$ with the medium category and the second cycle to $87.5 \%$ with the high category. Student responses showed $100 \%$ of students were happy with the application of the quartetcard game method.
\end{abstract}

Keywords: game method, quartet card, activeness, learning achievement, classification of living things

\section{PENDAHULUAN}

Salah satu materi IPA kelas 7 adalah klasifikasi makhluk hidup yang mempelajari tentang ciri-ciri makhluk hidup dan cara mengklasifikasikan makhluk hidup berdasarkan kesamaan ciri yang dimiliki. Pada materi ini siswa mulai mengenal nama ilmiah atau nama latin makhluk hidup. Berdasarkan pengamatan selama pembelajaran, siswa kesulitan dengan penggolongan makhluk hidupnya, nama ilmiah makhluk hidupnya dan contoh makhluk hidup yang belum pernah ditemui siswa.
Pembelajaran di sekolah untuk kelas VII masih teacher centered, yaitu segala aktivitas belajar mengajar berpusat pada guru. Guru menggunakan model ceramah yaitu guru menerangkan di depan kelas, siswa hanya mendengarkan, mencatat, dan mengerjakan tugas atau Lembar Kerja Siswa (LKS) yang diberikan. Guru juga tidak menggunakan media pembelajaran yang menarik dan inovatif. Hal ini menyebabkan anggapan bahwa faktor penentu utama keberhasilan siswa adalah guru. 
Keaktifan siswa belum muncul dalam proses pembelajaran ini karena siswa hanya mendengar kemudian berlatih soal. Siswa merasa malu untuk menanyakan hal yang sulit kepada guru, jarang bertanya dan mengemukakan pendapat. Siswa jarang untuk berdiskusi sehingga komunikasi dan interaksi antar siswa dengan siswa maupun dengan guru tidak terjalin dengan baik.

\section{Situasi}

pembelajaran

yang

menyenangkan merupakan salah satu aspek yang harus dipenuhi untuk mewujudkan pembelajaran yang efektif. Salah satu metode pembelajaran yang menyenangkan adalah metode permainan. Dalam permainan, terdapat unsur kesenangan, tanpa ada beban atau paksaan, dilakukan atas keinginan sendiri dan dilakukan dengan penuh perhatian.

Metode permainan membuat siswa merasa senang. Perasaan senang pada siswa akan siswa mempunyai minat yang tinggi dalam mengikuti pembelajaran. Menurut Winkel (Prasetyono, 2008: 51), jika dalam hati ada perasaan senang, maka biasanya akan menimbulkan minat. Bila diperkuat dengan sikap positif, maka minat akan berkembang dengan lebih baik. Menurut Dahlan (2010: 1), makna bermain pada anak pada dasarnya sama dengan belajar pada anak-anak. Melalui bermain, anak dapat mempelajari dirinya dan dunia sekitarnya.

Metode permainan merupakan salah satu metode yang baik dalam perkembangan kognitif seperti prestasi belajar siswa. Hal tersebut sesuai dengan pendapat dari Vigotsky (Santrock, 2002: 273), yang juga yakin bahwa permainan merupakan sistem yang sangat bagus bagi perkembangan kognitif. Hal tersebut di dasarkan pada karakteristik siswa yang sedang suka bermain, yaitu siswa akan lebih suka belajar pada situasi yang menyenangkan. Siswa juga akan lebih tertarik dengan berbagai permainan yang disuguhkan dalam pembelajaran, sehingga minat dan prestasi belajar siswa akan lebih meningkat.

Media merupakan alat bantu yang dapat dijadikan sebagai penyalur pesan guna mencapai tujuan pembelajaran. Untuk mencapai tujuan pembelajaran, guru dituntut untuk lebih kreatif dan inovatif dalam merancang dan menggunakan media pembelajaran. Menurut Sanaky (2009: 3) media pembelajaran adalah sebuah alat yang berfungsi dan dipergunakan untuk menyampaikan pesan pembelajaran.

Salah satu media pembelajaran yang digunakan dalam pembelajaran adalah kartu kwartet. Kartu kwartet berbentuk segi empat dengan gambar makhluk hidup di tengah kartu dan dilengkapi dengan deskripsi. Prasetya (2016:97) menyatakan bahwa media permainan kartu kwartet merupakan salah satu pengembangan media cetak berbasis visual. Media ini dihasilkan melalui proses pencetakan yang menghasilkan teks, grafik, dan foto/ gambar yang ditampilkan didalam kartu disertai ringkasan teks materi yang akan disampaikan.

Media kartu kwartet yang digunakan merupakan hasil pengembangan dari kartu kwartet yang sering digunakan anak-anak untuk bermain. Kartu kwartet pada klasifikasi makhluk hidup ini menggunakan gambar dan keterangan yang disesuaikan dengan materi pembelajaran. Setiap kartu terdiri dari gambar yang dilengkapi dengan nama kelompok dan 4 anggota kelompok. Nama kelompok dengan huruf kapital dan ditulis tebal sedangkan 4 anggota kelompoknya dengan huruf kecil. Anggota kelompok yang merupakan keterangan gambar ditulis sebelah kiri atas dan dicetak dengan warna berbeda (merah). Salah satu kartu kwartet pada gambar 1.

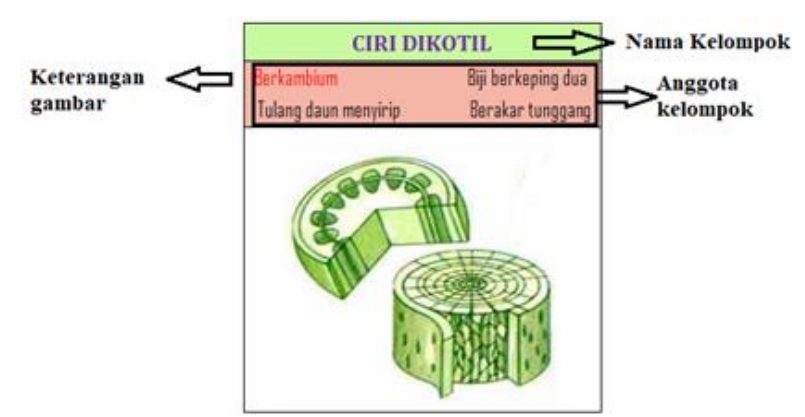

Gambar 1. Salah Satu Contoh Kartu Kwartet yang Dibuat

Ada 12 set kelompok kartu kwartet yang dilengkapi dengan anggota kelompok kartu. Nama kelompok dan anggota kelompok tersebut terdapat pada tabel 1 . 
Tabel 1. Kategori dan Keterangan Kartu Kwartet Klasifikasi Makhluk Hidup

\begin{tabular}{|c|c|c|}
\hline No & $\begin{array}{c}\text { Nama } \\
\text { Kelompok }\end{array}$ & Anggota \\
\hline 1 & Ciri monokotil & $\begin{array}{l}\text { - } \text { Berakar serabut } \\
\text { - Biji berkeping satu } \\
\text { - Tulang daun sejajar } \\
\text { - Tidak berkambium }\end{array}$ \\
\hline 2 & Ciri dikotil & $\begin{array}{l}\text { - } \quad \text { Berakar tunggang } \\
\text { - } \quad \text { Tulang daun menyirip } \\
\text { - } \text { Berkambium } \\
\text { - } \text { Biji berkeping dua }\end{array}$ \\
\hline 3 & $\begin{array}{l}\text { Contoh } \\
\text { monokotil }\end{array}$ & $\begin{array}{l}\text { - } \text { Pisang } \\
\text { - Jagung } \\
\text { - Kelapa } \\
\text { - Anggrek }\end{array}$ \\
\hline 4 & Contoh dikotil & $\begin{array}{l}\text { - } \text { Mangga } \\
\text { - Singkong } \\
\text { - } \text { Belimbing } \\
\text { - } \text { Pepaya }\end{array}$ \\
\hline 5 & $\begin{array}{l}\text { Contoh } \\
\text { Gymnospermae }\end{array}$ & $\begin{array}{l}\text { - } \text { Melinjo } \\
\text { - Cemara } \\
\text { - Pakis haji } \\
\text { - Pinus }\end{array}$ \\
\hline 6 & Tanaman paku & $\begin{array}{l}\text { - Semanggi } \\
\text { - Suplir } \\
\text { - } \text { Tanduk rusa } \\
\text { - Sarang burung }\end{array}$ \\
\hline 7 & Contoh Protista & $\begin{array}{l}\text { - Eucheuma spinosum } \\
\text { - Amoeba } \\
\text { - Paramaecium } \\
\text { - Euglena }\end{array}$ \\
\hline 8 & Contoh Mollusca & $\begin{array}{ll}\text { - } & \text { Kerang } \\
\text { - } & \text { Gurita } \\
\text { - } & \text { Bekicot } \\
\text { - } & \text { Cumi-cumi }\end{array}$ \\
\hline 9 & $\begin{array}{l}\text { Contoh } \\
\text { Coelenterate }\end{array}$ & $\begin{array}{l}\text { - Ubur-ubur } \\
\text { - Hydra } \\
\text { - Anemon } \\
\text { - Bunga karang }\end{array}$ \\
\hline 10 & Contoh Porifera & $\begin{array}{l}\text { - Euspongia } \\
\text { - Poterion } \\
\text { - Spongilla } \\
\text { - Scypha }\end{array}$ \\
\hline 11 & $\begin{array}{l}\text { Contoh } \\
\text { Arthropoda }\end{array}$ & $\begin{array}{l}\text { - Insecta (serangga) } \\
\text { - Myriapoda (Lipan) } \\
\text { - Crustacea } \\
\text { - Arachnoidea (laba } \\
\text { laba) }\end{array}$ \\
\hline 12 & $\begin{array}{l}\text { Contoh } \\
\text { Echinodermata }\end{array}$ & $\begin{array}{l}\text { - } \text { Bintang laut } \\
\text { - Lilia laut } \\
\text { - Landak laut } \\
\text { - Teripang \& bintang } \\
\text { ular }\end{array}$ \\
\hline
\end{tabular}

Sesuai latar belakang permasalahan, peneliti mengidentifikasi permasalahan antara lain: 1) guru menggunakan metode ceramah sehingga pembelajaran membosankan dan tidak menyenangkan, 2) pembelajaran tidak menggunakan media yang menarik dan inovatif, 3) siswa kesulitan dengan materi pada klasifikasi makhluk hidup, 4) prestasi belajar rendah dan 5) keaktifan siswa belum nampak.

Tujuan penelitian ini adalah: 1) meningkatkan prestasi belajar IPA pada materi Klasifikasi Makhluk Hidup kelas VII SMP Negeri 1 Semin, 2) meningkatkan keaktifan belajar siswa pada materi Klasifikasi Makhluk Hidup kelas VII SMP Negeri 1 Semin, dan 3) mengetahui respon siswa terhadap penerapan metode permainan kartu kwartet.

\section{METODE PENELITIAN Jenis Penelitian}

Penelitian ini merupakan Penelitian Tindakan Kelas (PTK).

\section{Waktu dan Tempat Penelitian}

Waktu penelitian adalah mulai bulan November 2018 sampai Juni 2019. Tempat penelitian di SMP N 1 Semin Gunungkidul.

\section{Subjek Penelitian}

Subjek penelitian ini yaitu siswa kelas 7C SMP 1 Semin Gunungkidul berjumlah 32 siswa. Prosedur

Penelitian ini menggunakan model penelitian dari Kemmis dan Mc Taggart (dalam Arikunto, 2006: 92) yang dilaksanakan dengan siklus yang berulang. Pelaksanaan penelitian ini terdiri atas 2 siklus. Masingmasing siklus 2 kali pertemuan. Ada 4 tahapan untuk setiap siklus, yaitu planning (perencanaan), action (tindakan), observation (pengamatan) dan reflection (refleksi).

Pelaksanaan penelitian ini didahului dengan observasi untuk mengetahui jalannya pembelajaran sebelum penerapan metode permainan kartu kwartet. Slangkah selanjutnya yaitu pelaksanaan pra siklus. Nilai kuis ini digunakan sebagai dasar untuk mengetahui kemampuan awal siswa.

Tahap perencanaan merupakan tahap persiapan perangkat yang dibutuhkan dalam penelitian tindakan kelas. Kegiatan yang dilaksanakan pada tahap perencanaan meliputi penyusunan Rencana Pelaksanaan Pembelajaran (RPP), LKS, lembar observasi pelaksanaan pembelajaran dan soal kuis. 
Tahap pelaksanaan merupakan penerapan perencanaan. Tahap pelaksanaan dilakukan oleh guru sebagai peneliti dan dibantu oleh pengamat (observer) dalam rangka pengumpulan data. Tahap pelaksanaan sesuai dengan RPP yang disusun.

Tahap pengamatan merupakan tahapan observer mengamati proses pembelajaran sesuai dengan instrument pengamatan yang telah dirancang oleh peneliti. Hal-hal yang diamati oleh observer adalah kegiatan yang dilakukan peneliti selama pembelajaran dan aktifitas siswa selama proses pembelajaran. Pengamat memberikan penilaian keaktifan siswa berdasarkan lembar observasi. Catatan permasalahan pada tahap observasi pembelajaran dianalisis dan dicari pemecahannya.

Tahap refleksi dilakukan untuk mengetahui hasil dari pelaksanaan tindakan. Jika hasil observasi atau tes belum baik maka perlu diadakan perbaikan pada siklus berikutnya. Hasil pembelajaran pada siklus I dilanjutkan dengan siklus kedua dengan menerapkan rancangan perbaikan pembelajaran siklus I.

Pelaksanaan pembelajaran diawali dengan pra penelitian, yaitu observasi pembelajaran sebagai dasar untuk mengetahui kebutuhan inovasi pembelajaran.

Data, Instrumen dan Teknik Pengumpulan Data Jenis data yang digunakan dalam penelitian ini adalah data kualitatif dan kuantitatif. Data kualitatif berupa lembar hasil observasi pembelajaran, sedangkan data kuantitatif berupa nilai hasil belajar siswa, hasil observasi keaktifan belajar siswa dan respon siswa terhadap penerapan media kartu.

Instrumen yang digunakan dalam penelitian ini adalah sebagai berikut:

1) Lembar observasi yang berisi tentang hasil observasi pembelajaran sebelum penelitian (pra penelitian) dan keaktifan belajar siswa

2) Angket siswa yang berisi tentang pendapat siswa tentang penerapan media pembelajaran kartu kwartet.

3) Lembar soal tes

4) Lembar nilai hasil belajar

5) Catatan kejadian yang berisi tentang aktivitas pembelajaran yang berlangsung di dalam kelas mulai dari siklus I dengan akhir siklus II.

6) Catatan hasil refleksi
Teknik pengumpulan data dilakukan dengan tes, kuesioner dan observasi. Tes digunakan untuk mengetahui tingkat pemahaman konsep klasifikasi makhluk hidup setelah peserta didik sebelumnya melakukan kegiatan pembelajaran. Kuesioner digunakan untuk mengetahui tanggapan siswa terhadap pelaksanaan tindakan yang dilakukan. Observasi digunakan untuk mengetahui aktivitas belajar siswa.

\section{Teknik Analisis Data}

Teknik analisis data dalam penelitian ini yaitu:

1) Analisis data hasil observasi pada lembar observasi yang diisi oleh pengamat mengenai aktivitas guru dan siswa selama proses pembelajaran. Hal ini dilakukan untuk mengetahui peningkatan aktivitas yang terjadi. Analisis keaktifan belajar siswa dapat diketahui dengan rumus sebagai berikut:

Keterangan:

$$
\mathrm{P}=\frac{\sum f x}{N} \times 100 \%
$$

$$
\begin{aligned}
\mathrm{P} & =\text { persentase keterlaksanaan } \\
& \text { pembelajaran } \\
\sum \mathrm{f} & =\text { jumlah skor yang diperoleh } \\
\mathrm{N} & =\text { jumlah skor maksimal semua } \\
& \text { komponen yang diambil (Indarti, } \\
& \text { 2008: 26) }
\end{aligned}
$$

2) Ketuntasan belajar siswa didapat dari nilai siswa di setiap akhir siklus. Analisis ini berpedoman pada pencapaian indikator keberhasilan yang sudah ditentukan sebelumnya. Hasil analisis prestasi belajar disajikan dalam bentuk persentase ketuntasan belajar. Ketuntasan hasil belajar secara klasikal dihitung dengan menggunakan rumus sebagai berikut.

Keterangan:

$$
\mathrm{P}=\frac{\sum n}{N} \times 100 \%
$$

$$
\begin{array}{ll}
\mathrm{P} & =\text { persentase ketuntasan klasikal } \\
\mathrm{n} & =\text { jumlah siswa yang tuntas belajar } \\
\mathrm{N} & =\text { jumlah seluruh siswa }
\end{array}
$$

(Sudjana, 2009: 129)

Tingkat ketuntasan belajar klasikal menggunakan kriteria sebagai berikut:

$$
\begin{array}{ll}
>80 \% & =\text { sangat tinggi } \\
60 \%-79 \% & =\text { tinggi } \\
40 \%-59 \% & =\text { sedang } \\
20 \%-39 \% & =\text { rendah } \\
<20 \% & =\text { sangat rendah }
\end{array}
$$

(Zainal, dkk., 2011:41) 
Indikator keberhasilan dari penelitian ini adalah 1) Persentase aktivitas siswa meningkat setiap siklusnya, dan mencapai predikat tinggi, 2) Adanya peningkatan rata-rata nilai setiap siklusnya dan 3) Tingkat keberhasilan siswa secara klasikal mencapai $\geq 75 \%$ dari total jumlah siswa telah lulus KKM dengan nilai sekurang-kurangnya 70.

\section{HASIL DAN PEMBAHASAN}

Berdasarkan hasil observasi awal, diperoleh data bahwa pembelajaran masih berpusat pada guru, guru hanya menggunakan metode ceramah, guru tidak menggunakan media pembelajaran yang menarik, keaktifan siswa kurang dan siswa kesulitan pada materi klasifikasi makhluk hidup. Kondisi ini menyebabkan pembelajaran menjadi membosankan. Setelah diadakan analisis hasil observasi pra-penelitian kemudian diadakan pre-test. Tes ini bertujuan untuk mengetahui tingkat pemahaman awal siswa terhadap materi yang akan diajarkan.

\section{Deskripsi Siklus 1}

Pelaksanaan tahapan pada siklus 1 sesuai dengan rancangan yang dibuat. Siklus 1 terdiri dari 2 kali pertemuan. Peneliti sebagai pengajar melaksanakan kegiatan pembelajaran sesuai dengan RPP yang dsusun pada tahap perencanaan. Langkah pembelajaran pada pertemuan 1 ini yaitu: 1) Guru menentukan topik/materi permainan yang akan digunakan dalam pembelajaran, 2) Guru menyiapkan alat dan bahan permainan yang dibutuhkan, 3) Guru menyusun petunjuk atau langkahlangkah pelaksanaan permainan, 4) Guru menjelaskan kepada siswa maksud dan tujuan serta peraturan permainan terlebih dahulu, 5) guru membagi siswa menjadi 8 kelompok, 6) guru membimbing siswa melaksanakan kegiatan permainan, 7) Siswa mempresentasikan hasil permainan, 8) Guru memberikan kesimpulan mengenai pengertian atau konsep yang dimaksud dalam tujuan pembelajaran. Jumlah kartu yang digunakan pada pertemuan 1 adalah 4 set kartu.

Pada tahap observasi, peneliti dan guru kelas melakukan kegiatan pengamatan dalam proses pembelajaran di kelas. Pada tahap refleksi, peneliti dan observer menganalisis dan mengevaluasi data yang telah diperoleh dari kegiatan observasi.

Langkah-langkah kegiatan pada pertemuan ke 2 sama dengan pertemuan pertama, tetapi pada pertemuan 2 menggunakan 6 set kartu dari total 12 set kartu kwartet yang dibuat. Pada akhir pelaksanaan siklus ke 2 dilakukan kuis.

Hasil observasi siswa pada pelaksanaan pembelajaran pada siklus 1 adalah: 1) Ada siswa yang tidak memperhatikan saat guru menjelaskan, bermain sendiri dan mengobrol dengan teman satu kelompok, 2) Kerjasama dalam kelompok belum berjalan dengan baik, 3) Keaktifan siswa belum muncul secara bagus, hanya siswa tertentu saja yang mau untuk mengerjakan soal. 4) Saat kuis individu, masih banyak siswa yang berusaha untuk mencontek jawaban temannya.

Berdasarkan permasalahan-permasalahan di atas, peneliti merumuskan tindakan perbaikan sebagai alternatif pemecahan masalah untuk pertemuan pada siklus II tersebut, antara lain: 1) Guru bersikap tegas dan mengingatkan kepada siswa konsentrasi belajar supaya lebih bisa memahami materi dan 2) Guru memberikan pengawasan dengan cara berkeliling dari satu kelompok ke kelompok lain.

\section{Deskripsi Siklus II}

Tahapan kegiatan pada siklus II secara umum sama dengan kegiatan pada siklus I. Perbedaanya adalah materi dan jumlah set kartu yang digunakan. Pada siklus ini dilakukan perbaikan pelaksanaan tindakan yang berdasarkan pada hasil refleksi siklus I yang telah diuraikan sebelumnya. Setelah kegiatan pertemuan ke 2 dilakukan pengambilan kuis kedua. Setelah selesai mengerjakan, soal langsung dibahas untuk mengetahui jawaban yang benar.

Hasil observasi siswa pada siklus 2 adalah: 1) Siswa sudah nyaman dengan kelompoknya masing-masing, 2) Siswa terlihat lebih bersemangat, aktif dalam hal bertanya, menjawab dan menyampaikan gagasan, 3) Suasana presentasi terlihat ramai tetapi teratur, 4) Siswa berusaha untuk menunjukkan kelebihan kelompok masingmasing, 5) Saat kuis individu, tidak ada siswa yang berusaha mencontek jawaban temannya.

Data kuantitatif yang diambil berupa nilai kuis, keaktifan siswa dan angket respon siswa terhadap pembelajaran. data ini kemudian dianalisis secara kualitatif. Nilai kuis 1 dan 2 dan ketuntasan belajar ditunjukkan pada tabel 2 dan gambar 3 di bawah ini. 
Tabel 2. Nilai pra siklus, kuis 1 dan kuis 2

\begin{tabular}{lccc}
\hline & \multicolumn{3}{c}{ NILAI } \\
\cline { 2 - 4 } & Pra & Siklus & Siklus \\
& siklus & 1 & 2 \\
\hline Nilai terendah & 33 & 50 & 53 \\
Nilai tertinggi & 80 & 90 & 93 \\
Rata-rata & 53.5 & 74,4 & 77.0 \\
Jumlah tuntas & 2 & 22 & 27 \\
Jumlah tidak & 30 & 10 & 5 \\
tuntas & & & \\
$\begin{array}{l}\text { Presentase } \\
\text { ketuntasan }(\%)\end{array}$ & 6.25 & 68.75 & 84.375 \\
\hline
\end{tabular}

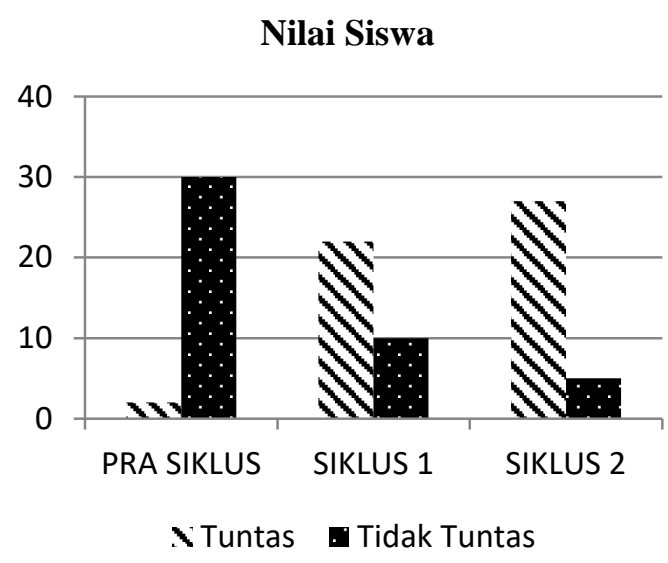

Gambar 2. Diagram nilai pra siklus, kuis siklus 1 dan kuis siklus 2

Berdasarkan hasil kuis pada pra siklus, siklus 1 dan siklus 2 terdapat peningkatan ratarata nilai dan presentase ketuntasan siswa. Hasil ini menunjukkan bahwa penggunaan metode permainan dengan media kartu kwartet dapat meningkatkan prestasi belajar. Permainan merupakan kegiatan yang menyenangkan, tidak membosankan dan mengasyikkan. Dengan kegiatan bermain menggunakan kartu kwartet yang berisi materi pelajaran, siswa sekaligus mempelajari materi tersebut. Tanpa disadari, siswa bermain sambil sekaligus belajar.

Selama kegiatan pembelajaran, siswa bermain kartu kwartet yang berisi materi pembelajaran klasifikasi makhluk hidup. Contohnya pada kelompok ciri monokotil, siswa akan belajar tentang ciri-ciri monokoti yang terdiri atas berakar serabut, biji berkeping satu, tulang daun sejajar dan tidak berkambium. Susanto (2009: 20) menyatakan bahwa permainan dapat berfungsi menanamkan materi dalam ingatan menjadi lebih lama, memberikan pencerahan saat mengalami kejenuhan, dan sebagai penguat dalam membuat kesimpulan di akhir pertemuan.

Permainan kartu kwartet ini menggunakan kartu kwartet tiruan seperti kartu kwartet mainan anak-anak dan cara bermainnya juga sama dengan permainan kartu kwartet. Menurut Sardiman (1996: 113), metode simulasi/permainan merupakan cara penyajian pelajaran dengan menggunakan situasi tiruan atau berpura-pura melalui sebuah permainan dalam proses belajar untuk memperoleh pemahaman tentang suatu konsep, prinsip, atau keterampilan tertentu.

Penerapan metode permainan ini juga meningkatkan keaktifan belajar siswa. Hasil observasi keaktifan belajar siswa ditunjukkan pada Tabel 3.

Tabel 3. Hasil observasi keaktifan belajar pada siklus 1 dan 2

\begin{tabular}{clcc}
\hline & Aspek Pengamatan & \multicolumn{2}{c}{ Skor Penilaian } \\
\cline { 3 - 4 } Kegiatan & 1. Bersemangat & 3 & Siklus 1 \\
Awal & 2. Antusias & 3 & 4 \\
& 3. Menjawab pertanyaan & 2 & 4 \\
& 4. Merespon masalah & 2 & 3 \\
& 1. Bekerja dalam kelompok & 3 & 4 \\
Kegiatan & 2. Membantu teman & 2 & 4 \\
Inti & 3. Mempresentasikan & 3 & 3 \\
& 4. Menanggapi hasil diskusi & 3 & 4 \\
& 5. Bertanya & 3 & 4 \\
& 6. Memberikan pendapat & 2 & 3 \\
Penutup & 1. Merangkum & 3 & 3 \\
& 2. Menerima tugas dengan senang & 2 & 3 \\
\hline \multirow{2}{*}{ Jumlah } & 31 & 42 \\
& $\quad$ Presentase & $64 \%$ & $87,5 \%$ \\
\hline
\end{tabular}


Penerapan metode permainan kartu kwartet dalam pembelajaran dapat membuat siswa terlibat aktif dalam pembelajaran. Metode permainan membuat kelas akan menjadi lebih menyenangkan, suasana belajar penuh ceria dan semangat. Metode dan media ini memberikan stimulus kepada siswa yang tadinya pasif dan takut melakukan kesalahan di depan teman atau guru, menjadi aktif dan berani berbicara untuk tanya jawab. Siswa lebih mudah berinteraksi dengan teman karena siswa merasa seperti bermain dengan teman sepermainan. Dengan kemudahan interaksi ini, siswa menjadi mudah mengoreksi apabila terjadi kesalahan dalam mengerjakan tugas.

Salah satu penentu keberhasilan belajar individu di sekolah adalah media dan metode yang digunakan guru. Guru sebagai pembimbing di sekolah diharapkan mempunyai kreativitas dalam mengembangkan metode pembelajaran agar siswa tidak cepat merasa jenuh atau bosan. Metode merupakan faktor eksternal yang mempengaruhi belajar seorang siswa (Sugihartono dkk. 2007: 76). Metode pembelajaran yang baik akan membantu siswa untuk bisa belajar dengan baik. Metode pembelajaran yang dipilih harus selalu disesuaikan dengan hakikat pembelajaran, karakteristik peserta didik, jenis materi pelajaran, situasi, kondisi lingkungan, dan tujuan yang ingin dicapai (Rohman, 2009: 180).
Penggunan media kartu kwartet membuat pembelajaran lebih menarik dan bervariasi sehingga siswa tidak bosan. Hal ini sejalan dengan manfaat media pembelajaran dalam proses belajar siswa menurut Sudjana dan Rivai (2002: 2) yaitu pembelajaran lebih menarik perhatian siswa, bahan pembelajaran akan lebih jelas dipahami oleh siswa, memungkinkan menguasai dan mencapai tujuan pengajaran, dan siswa tidak bosan dan guru tidak kehabisan tenaga.

Media pembelajaran mempunyai peran yang cukup berarti di dalam proses belajar mengajar. Hernawan (2007: 12) berpendapat ada beberapa keuntungan bahwa dengan menggunakan media pembelajaran, antara lain memungkinkan siswa berinteraksi secara langsung dengan lingkungannya. membangkitkan motivasi belajar siswa dan mengatasi keterbatasan waktu dan ruang.

Penggunaan media ini sesuai Sesuai dengan Permendikbud Nomor 22 Tahun 2016 tentang Standar Proses Pendidikan Dasar dan Menengah, sebuah proses pembelajaran pada satuan pendidikan diselenggarakan secara interaktif, inspiratif dan menyenangkan, sehingga peserta didik berpartisipasi aktif, sesuai dengan bakat, minat, dan perkembangan fisik serta psikologis peserta didik.

Tabel 4. Angket respon siswa terhadap pembelajaran

\begin{tabular}{lllcc}
\hline \multirow{2}{*}{ No } & Pernyataan & \multicolumn{2}{c}{ Skor } & \multirow{2}{*}{ Tidak } \\
\cline { 2 - 4 } & Yalalui metode permainan kartu kwartet memudahkan saya & 32 & & 100 \\
2 & $\begin{array}{l}\text { mengingat/menghapal materi klasifikasi makhluk hidup } \\
\text { Melalui metode permainan kartu kwartet memudahkan saya } \\
\text { memahami materi klasifikasi makhluk hidup }\end{array}$ & 32 & 100 \\
3 & $\begin{array}{l}\text { Saya senang jika pembelajaran materi klasifikasi makhluk hidup } \\
\text { dilaksanakan dengan metode permainan kartu kwartet }\end{array}$ & 32 & 100 \\
4 & $\begin{array}{l}\text { Saya dapat memperoleh pengalaman baru dalam pembelajaran } \\
\text { klasifikasi makhluk hidup melalui metode permainan kartu kwartet }\end{array}$ & 32 & 100 \\
5 & $\begin{array}{l}\text { Melalui metode permainan kartu kwartet ini saya lebih aktif } \\
\text { berpartisipasi dalam diskusi kelompok }\end{array}$ & 2 & 91 \\
6 & $\begin{array}{l}\text { Dengan saling interaksi antar teman saya lebih mudah mengoreksi } \\
\text { apabila terjadi kesalahan dalam mengerjakan tugas }\end{array}$ & 31 & 1 & 93 \\
7 & $\begin{array}{l}\text { Saya semangat untuk mengikuti pembelajaran dengan metode } \\
\text { permainan kartu kwartet }\end{array}$ & 32 & 0 & 100 \\
8 & $\begin{array}{l}\text { Saya merasa tidak bosan selama melaksanakan pembelajaran } \\
\text { dengan metode permainan kartu kwartet }\end{array}$ & 30 & 0 & 91 \\
9 & $\begin{array}{l}\text { Saya menginginkan metode permainan kartu ini juga digunakan } \\
\text { untuk materi pelajaran lain }\end{array}$ & 30 & 2 & 91 \\
\hline
\end{tabular}


Berdasarkan angket respon siswa terhadap penerapan metode permainan kartu kwartet, siswa menunjukkan respon yang baik. Siswa merasa bahwa permainan kartu kwartet memudahkan mengingat materi klasifikasi makhluk hidup. Sebagian besar materi ini adalah materi pengklasifikasian yang membutuhkan ketrampilan hafalan. Permainan ini tidak hanya dilakukan satu kali saja tetapi dilakukan berulang-ulang. Dengan perulangan ini membuat siswa lebih mudah menghafal materi klasifikasi makhluk hidup.

Siswa merasa senang dengan penerapan metode permainan kartu kwartet sehingga memudahkan memahami materi klasifikasi makhluk hidup. Kartu kwartet yang berisi gambar sebagai penguat pemahaman konsep membuat siswa lebih tertarik. Hal ini sesuai dengan pendapat Levie \& Lentz (dalam Arsyad, 2007: 17) tentang fungsi media khususnya media cetak berbasis visual yaitu fungsi atensi, yaitu menarik dan mengarahkan perhatian siswa untuk berkonsentrasi pada isi pelajaran yang berkaitan dengan makna gambar yang ditampilkan atau menyertai teks materi pelajaran, dan fungsi kognitif, yaitu gambar maupun lambang visual dapat memperlancar pencapaian tujuan untuk memahami dan mengingat informasi atau pesan yang terkandung dalam gambar.

Sebagian besar siswa juga bersemangat untuk mengikuti pembelajaran dengan metode permainan kartu kwartet. Hal ini mengurangi efek kebosanan siswa selama melaksanakan pembelajaran ini. Siswa juga menginginkan metode permainan kartu ini digunakan untuk materi pelajaran lain. Dengan bermain, siswa merasa tertarik dan senang untuk belajar. Ketika siswa sudah merasa senang untuk belajar diharapkan siswa dapat menunjukkan sikap positif terhadap pembelajaran sehingga efektivitas pembelajaran yang berkualitas dapat diwujudkan. Menurut Ahmadi dan Munawar (2005: 105), permainan merupakan suatu perbuatan yang mengandung keasyikan dan dilakukan atas kehendak sendiri, bebas tanpa paksaan dengan bertujuan untuk memperoleh kesenangan pada waktu mengadakan kegiatan tersebut.

Setiap metode pasti memiliki kelemahan dan kelebihan. Kelebihan metode permainan berdasarkan pengamatan selama pembelajaran antara lain: 1) siswa lebih aktif dan senang dengan pembelajaran tersebut, 2) siswa lebih asyik karena pembelajaran berlangsung santai dan tanpa paksaan, 3) proses belajar lebih efektif karena adanya umpan balik langsung, dan 4) dapat menerapkan konsep ke dalam situasi sebenarnya. Kekurangan metode permainan yang sudah dilakukan adalah: 1) membutuhkan waktu dan biaya yang lebih untuk mempersiapkannya dan 2) siswa terkadang cenderung ramai karena merasa belajar dengan bebas.

Penggunaan media kartu kwartet dalam pembelajaran juga memiliki kelebihan dan kekurangan. Kelebihannya adalah: 1) dapat menghadirkan tiruan dari objek dan gambar yang sebenarnya dari masing-masing nama kelompok kartu, 2) tidak membutuhkan alat pendukung penyajian gambar yang lain, 3) merupakan media yang menarik karena terdapat gambar-gambar, 4) tidak membutuhkan tempat dan waktu yang khusus, 5) membantu siswa membuat konsep abstrak ke konsep konkret, dan 6) siswa lebih mudah memahami dan mengingat informasi atau pesan yang terkandung dalam gambar. Kekurangan media kwartet antara lain: 1) membutuhkan waktu yang lama untuk mempersiapkannya dan 2) kertas mudah rusak jika terkena air.

\section{SIMPULAN DAN SARAN}

Pembelajaran IPA dengan penerapan metode permainan kartu kwartet pada materi Klasifikasi Makhluk Hidup dapat meningkatkan prestasi belajar dan keaktifan belajar siswa. Prestasi belajar yang ditunjukkan dengan ketuntasan belajar klasikal mengalami kenaikan, yaitu prasiklus adalah $6,25 \%$, siklus I adalah $68.75 \%$ dan siklus II meningkat menjadi sebesar $84.375 \%$ dengan kategori tinggi. Pembelajaran ini meningkatkan keaktifan belajar, yaitu rata-rata siklus I adalah 64\%, sedangkan siklus II menjadi $87,5 \%$. Respon siswa terhadap pembelajaran menunjukkan $100 \%$ siswa senang dengan penerapan metode permainan kartu kwartet.

Saran untuk guru agar mengembangkan metode dan media pembelajaran yang lebih variatif supaya siswa lebih termotivasi untuk belajar sehingga dapat meningkatkan hasil belajar. Siswa diharapkan lebih aktif sehingga pembelajaran lebih interaktif antara guru dan siswa. Siswa diharapkan mampu melaksanakan diskusi dan mampu bekerjasama dengan teman satu kelompok. 
DAFTAR PUSTAKA

A.M., Sardiman. (1996). Interaksi dan Motivasi Belajar Mengajar. Jakarta: Raja Grafindo Persada.

Ahmadi, A. \& Munawar, S. (2005). Psikologi Perkembangan. Jakarta: Rineka Cipta

Arikunto, S. (2006). Prosedur Penelitian Suatu Pendekatan Praktik. Jakarta: Rineka Cipta.

Arsyad, A. (2007). Media Pembelajaran. Jakarta: PT Grafindo Persada.

Dahlan, T. (2010). Games Sains Kreatif dan Menyenangkan untuk Meningkatkan Potensi Kecerdasan Anak. Bandung: Ruang Kata

Hernawan, A.H.. dkk. (2007). Media Pembelajaran Sekolah Dasar. Bandung: UPI Press

Indarti, T. (2008). Penelitian Tindakan Kelas (PTK) dan Penulisan Ilmiah. Surabaya: Lembaga Penerbitan Fakultas Bahasa dan Seni Universitas Negeri Surabaya.

Peraturan Menteri Pendidikan Nasional Republik Indonesia Nomor 22 Tahun 2006 Tentang Standar Isi untuk Satuan Pendidikan Dasar dan Menengah.

Prasetya, Y.E. (2016). Pengembangan Media Permainan Kartu Kwartet Dalam Pembelajaran Matematika Pada Materi Pokok Segitiga Dan Segiempat. MATHEdunesa Jurnal Ilmiah Pendidikan Matematika. 1(5): 95-101. Retrieved from http://jurnalmahasiswa.unesa.ac.id/ index.php/mathedunesa/article/view/166 $73 / 15144$
Prasetyono, D.S., (2008). Rahasia Mengajarkan Anak Gemar Membaca Pada Anak Sejak Dini. Yogyakarta: Think

Rohman, A. (2009). Memahami Pendidikan dan Ilmu pendidikan. Yogyakarta: UNY Press

Sanaky, H.A.H. (2009). Media Pembelajaran. Yogyakarta: Safiria Insania Press.

Santrock, J.W. (2002). Perkembangan Masa Hidup Jilid 1. (Terjemahan oleh Juda Damamik \& Achmad Chusairi). Jakarta: Erlangga

Sudjana, N. dan Rivai, A. (2002). Media Pengajaran. Bandung: Sinar Baru Algesindo.

Sudjana, N. (1989). Penilaian Hasil Proses Belajar Mengajar. Bandung: PT Remaja Rosdakarya.

Sugihartono, dkk. (2007). Psikologi Pendidikan. Yogyakarta: UNY Press

Susanto, E. (2009). 60 Games untuk Mengajar, Membuka dan Menutup Pelajaran. Yogyakarta: Lumbung Kita.

Zainal, A. dkk. (2011). Penelitian Tindakan Kelas untuk Guru SD, SLB dan TK. Bandung: Yrama Widya 